\title{
Twin Ritual (Kamta Bulikur): The Significance of Traditional Music in the Health and Wellbeing of Twins among the Bura of North-east Nigeria
}

\author{
Christopher Yusufu Mtaku \\ Senior Lecturer, Department of Visual and Performing Arts, \\ University of Maiduguri, Nigeria \\ cymtaku@gmail.com
}

Received: April 27, 2016 / Accepted: September 5, 2016 / Published: December 16, 2016

\begin{abstract}
Similar to many African communities, the Bura of northeast Nigeria believe that twins are born with supernatural powers. Among such powers are the ability to die and be reborn by another woman, the use of scorpions to harm people at will and the ability to feign sickness. To counteract such powers, a special twin ritual, kamta bulikur, must be performed for the health and wellbeing of every twin. Bura traditional music is an integral part of this twin ritual. This paper examines Bura notions of twinship and the significance of traditional music in the kamta bulikur ritual.
\end{abstract}

Keywords: Bura, twins, music, health and wellbeing, ritual

Twins in most African communities were, and are, to some extent, still considered to be extraordinary beings. Diverse customs and beliefs pertaining to twins, therefore, exist among many communities; especially in West African communities, where there is the highest rate of twin births (Pison, van Beek, Sala-Diakanda, 1999, Pison, van Beek, Sala-Diakanda, et al., 1989; Oruene, 1983; Stewart, 2000). In western Nigeria, Benin and Togo, the rate is over 2.5 twin births per 1000 (Pison et al., 1989, p. 259). The Mega-Chad area, of which Buraland is part, has an average of 1.5-2 twin births per 1000 (van Beek, 2002, p. 121; Pison et al., 1989, p. 260). The African continent undoubtedly, therefore, could be said to have a very high rate of twin births.

Many of the customs and beliefs pertaining to twin births in West Africa are geared towards the health and wellbeing of twins. As stated earlier, twins are considered extraordinary beings, possessing extraordinary powers that can be used to harm their siblings, an individual or a society as a whole. The extraordinary powers believed to be possessed by them can also be detrimental to their health and wellbeing. Due to the possession of such extraordinary powers, it is said, twins cannot live a normal life like other members of society. The general belief is that twins are not of "this world"

(van Beek, 2002, p. 131), and in order to reduce to the minimum or completely avert the dangers posed by them, efforts are geared towards incorporating or appeasing them to be part of or at least be tolerant of the society into which they are born. According to Leroy, Olaleye-Orune, Koeppen-Schomerus and Bryan (2002):

In traditional African societies, twins are considered of preternatural origin and raise emotional reactions oscillating from fear and repugnance to hope and joy... 
Twins can bring about disaster, disease and death ... As a result [they are] treated with all due respect, loving and care. (p. 134)

Thus, "it is not so much identical twins that fascinate Africa; that particular fascination is for the scientific North with its deep curiosity regarding the balance between nature and nurture, genetics and education" (van Beek, 2002, p. 121). In West Africa, instead, it is the concern to contain the emotional reactions created by the beliefs in the preternatural origin of twins that matters (Zazzo, 1960 \& 1993). In most African communities, therefore, twins were and are, to some extent, not viewed with favour. Many of these communities have, therefore, come up with appropriate rituals to take care of the concerns pertaining to twins. In their study of Yoruba customs and beliefs pertaining to twins, Leroy et al. (2002) observe that:

Mainly for genetic reasons, the Yoruba happen to present the highest dizygotic twinning rate in the world ( $4.4 \%$ of all maternities). The high rate associated with such pregnancies has contributed to the integration of special belief system in the African traditional religion of this tribe. (p. 132)

In Nigeria it is not only the Yoruba that have integrated a special belief system pertaining to twins in their traditional religion. Many other groups, including the Bura - though with a very small twining rate compared to the Yoruba - perform twin-related rituals considered necessary for the health and wellbeing of twins. This article considers Bura twin rituals performed to counteract the commonly held beliefs or notions relating to twins. For the health and wellbeing of twins, the Bura consider the rituals necessary during the life time of each twin. This study focuses mainly on the significance of music in the rituals. There is a growing body of research investigating the relationship between music, health and wellbeing. Much of this research, though, focuses more on the curative and therapeutic functions of music in clinical settings (MacDonald, Kreutz \& Mitchell, 2012; Knox, Beveridge, Mitchell, \& MacDonald, 2011; Bechtold, Puli, Othman, Bartalos, Marshall \& Roy, 2009; Enwall \& Duppils, 2009). This paper, however, seeks to consider how music provides a curative and therapeutic function but in a different setting - Bura twin rituals; a traditional procedure believed to 'cure' twins from all, or lessen, the dangers that they pose to the society. For a proper understanding of the significance of music in the rituals, the belief system of the people concerning twins is explored as well.

The data for this paper was primarily derived from fieldwork. Interviews were conducted with several knowledgeable Bura elders who, due to the on-going Boko Haram insurgency in the region, wish to remain anonymous. ${ }^{1}$ Also, very little evidence of the music is presented in this paper. This is because dozens of traditional musicians in the northeast of Nigeria were targeted and murdered by Boko Haram simply for their artistry. The Boko Haram sect is totally against music. As a result, those musicians who managed to escape the terror of the group are very reluctant to perform.

\section{The Bura}

\footnotetext{
${ }^{1}$ Boko Haram is a terrorist group fighting to create an Islamic State in Northern Nigeria since 2009.
} 
The Bura people live in Borno State in the northeast of the Federal Republic of Nigeria (Figure 1). Borno State is characterized by a remarkable degree of ethno-linguistic and cultural diversity. Apart from the Kanuri and Shuwa, who populate the central and northern areas of Borno State, the south is occupied by a large number of ethnic groups who speak languages belonging to the Chadic language family. Among them, the Bura are the most populous as well as the economically and politically most influential people. They settled predominantly on the Biu Plateau, a rugged volcanic area that rises up to 762 meters above sea level. A small population of the Bura lives in the states of Adamawa and Yobe, both bordering Borno State.

There are two hypotheses about the origin of the Bura people. According to those accounts, they may have either migrated from Asante in the west (present-day Ghana) or from the Cameroon Mountain range in the east (Davies, 1954; Meek, 1931). In the fifteenth century, Bura-speaking groups, the Pabir, formed some kind of a state with their capital close to Biu. Having embraced Islam early, the Pabir had good economic and political contacts in the Borno Emirate, under whose influence they are still partially living today. Ever since those days, tension has persisted between the Pabir and Bura people, a situation which could neither be erased under colonial rule in the twentieth century nor within the political context of present-day Nigeria.

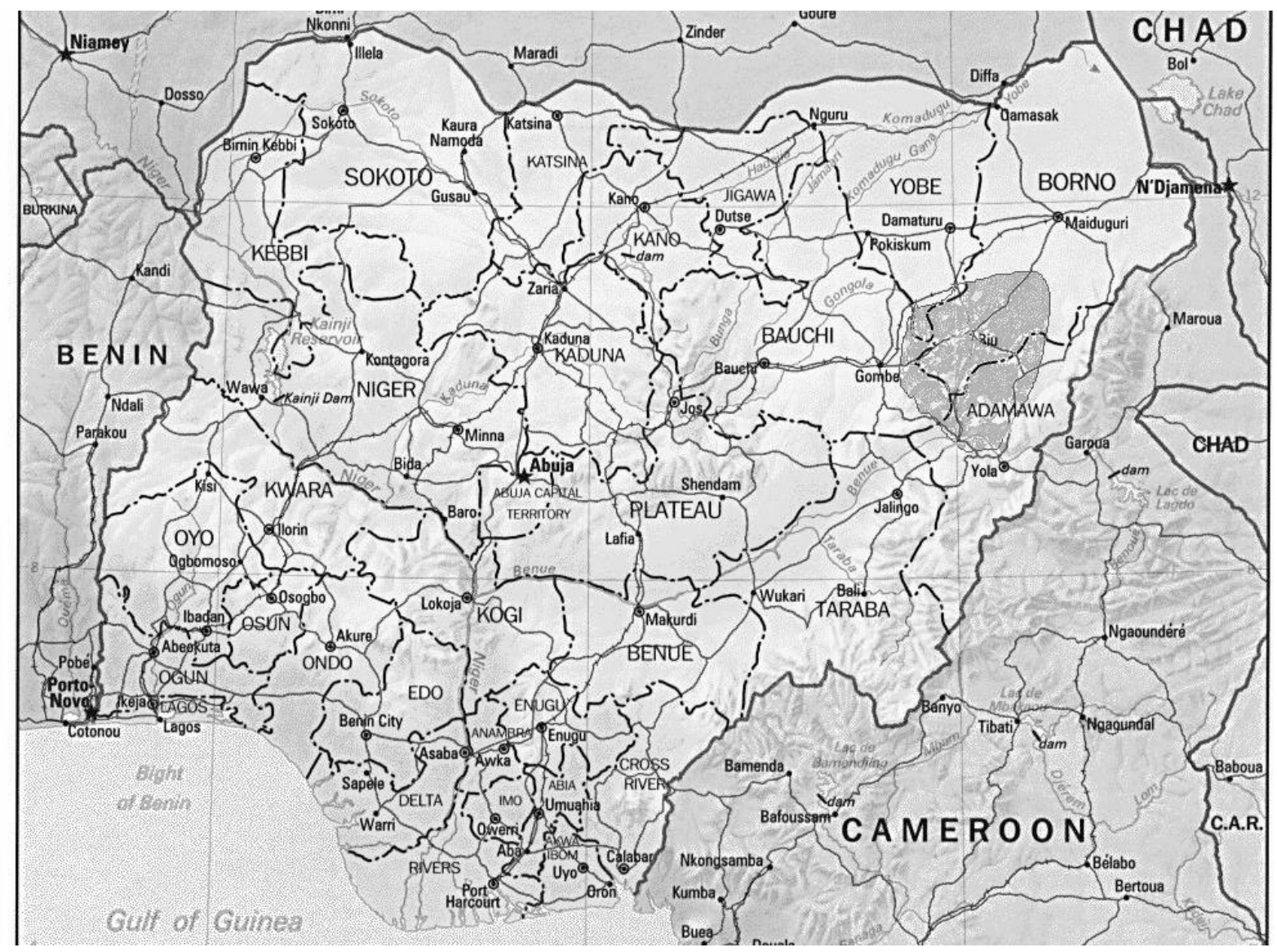

Figure 1: Map of Nigeria showing Buraland shaded grey in the northeast (source: http://www.reocities.com/Athens/6060/buralandmap.htm) 
Spirits (shatan) are believed to inhabit the Bura world and people's lives are overshadowed by the fear of offending the spirits. ${ }^{2}$ Before the advent of Christianity, each adult possessed a personal god, the hyelkir, or "god head" (one of the haptu spirit types), represented as a statuette and usually kept in the owner's bedroom. Each compound had a household haptu shrine, an important center for worship through which protection from danger was sought. In each village, there was a haptu shrine, where inhabitants publicly worshipped.

Apart from the possession of haptu, there existed - and to some extent still exists - the belief in an impersonal power which is in a special way possessed by certain humans and animals and, at times, concentrated in objects like mispar (charms and amulets), shafa (a kind of tree), milim and jisku (both stone gods). The Bura believe, too, that humans and all animate beings possess shangur, the life principle or soul life. In many cases, the shangur of a wild animal is associated with a person. A person whose shangur is associated with a wild animal, it is said, "can have the animal steal, kill or maim for him without any effort on his part. Of course if the bush animal becomes sick or tired, he too is sick or tired and if it is killed, he likewise dies" (Bittinger, 1939, p. 3). This practice in particular is more common among the Kilba people living to the east of Bura land, but it is also found among the Bura people sharing borders with them.

Above all is the belief in the supreme, all-powerful deity of the Bura people, recognized under the title of hyel. According to Bura folklore, hyel lived near human beings until man's disobedience forced him to withdraw into a new universe. He then became too distant to be directly influenced by human agencies, but in every act of traditional worship the name of hyel is mentioned to seek help in all matters.

A significant shift in Bura history was brought about by the commencement of missionary work of the Church of the Brethren Mission in 1922. Many people turned to Christianity, partially attracted by the educational and health care system that, all of a sudden, offered a new way of life to them. At the same time, some Bura also turned to Islam as the religion gradually made inroads into the area. Despite the conversion of many Bura people to Christianity and Islam, some still adhere to their traditional religion. Even among those that embraced the new religions, certain traditional practices are still evident, especially the kamta bulikur rites. Many of the converts to the new religions still turn to the twin ritual, especially when it is evident that the health and wellbeing of twins within a family are at "risk". Such risks are noticed when twins begin to exhibit the attributes associated with them - for example, frequent illness and failure to get married early.

\section{Bura Kamta Bulikur Ritual}

The Bura term for twin is buli. When one speaks of twins, it is generally understood as people born of the same mother at the same time. In the Bura worldview, though, this might not necessarily be the case. A single child could be considered to be a twin depending on the circumstances surrounding the birth and the character of the child as he/she matures into adulthood. A child could be born single but if suspected to be a reincarnation, attention is paid to see whether he/she would exhibit the traits related to twins. If such traits are noticed, the child is

\footnotetext{
${ }^{2}$ The Bura have many spirits that are known by different names but are collectively spoken about as shatan. Thus, for example, the spirit connected to rivers would be referred to as shatan kuta Hawul while that of the hills would be referred to as shatan Gar. Jang is also one of the spirit types. Different characters are attributed to the spirits. Some are of good character (e.g the haptu) while some (e.g. jang) are malevolent.
} 
labelled as a twin and treated as one. This is so because the people believe in the ability of certain children who were "meant to be born as twins" to die and be reborn by another woman, a process of reincarnation which only twins are thought to be capable of actualizing. Such a child is referred to as bzir sisi (reincarnated child), and in Bura worldview is believed to have the same traits as those actually born as twins. A child thought to be a reincarnation is feared and receives the same treatment as a twin in Bura society.

Generally speaking, Bura beliefs concerning twins are similar to those of some communities neighboring them (Leroy et al., 2002; van Beek, 2002; Chappel, 1974). According to such Bura beliefs, twins possess powers that non-twin children do not have. As a result of this, twins are looked after carefully lest they be annoyed and cause danger to their immediate family members or to the society as a whole. The dangers posed by infuriated twins could come in several ways. It could be by sending a scorpion to sting anyone who offends him/her, or dying and being born by another woman, or refusing to grow physically. In short, any calamity that befalls a family that has twins in its membership could easily be linked with the manner the twin is treated. It is sometimes believed that twins use ill health as a means of getting the attention of the other family members, thereby, distracting them from engaging in any activity that sustains the means of their livelihood (e.g. farming). When a twin is constantly sick, all the people of the household would be worried and suspend all other activities so as to look after him/her. Sometimes, ill health feigned by twins goes beyond being merely physically sick in the body; it could be psychological problems, which in most cases are interpreted as "madness". Such problems are noticed through the behavior of a twin.

When a twin begins to behave beyond the conventional practices of the society, it is believed that the spirits of the "other world" are responsible. A mental state of this nature, in the Bura worldview, is detrimental to the health and wellbeing of twins. Equally, when the life cycle of a twin is interrupted, it is as well associated with the belief that twins belong to "another world". The life cycle of a person according to Bura worldview is that he/she is born, grows up and is initiated into adulthood, marries and raises a family and subsequently dies, only to be reintegrated with the ancestral world. Of crucial importance to the Bura is the stage of being initiated into adulthood and marrying in order to raise a family. When marriage is, therefore, delayed in the life of a twin, it is as well associated with him/her being part of "another world". The "other world", according to Bura worldview, consists of spirits, some of whom are thought to be directly responsible for the behavior of twins. A twin's inability to marry early in life is thought not to be unconnected with the fact that he/she has a "wife" or "husband" in the spirit world. This is considered by the Bura to be detrimental to the twin's wellbeing. The belief is that such a spiritual wife or husband would never allow a twin to marry until the relationship is severed. Therefore, for a twin to marry early, as expected by society, he/she must be separated from the wife or husband he/she is believed to have in the spiritual realm.

As a result of all the above beliefs about twins, the Bura perform some rituals at different stages in the lifetime of each twin in order to ensure his/her good health and wellbeing. The first is performed to name the child, vah thlim, while the second, kamta bulikur, is performed when some of the beliefs mentioned earlier begin to be noticed in the life of a twin. Concerning the first ritual, the Bura have no special naming rites for children except for twins. A traditional medicine man, deaha, and a traditional musician play key roles at the naming ritual of twins. When a woman gives birth to twins, the deaha is invited to perform the naming ritual. The parents of the twin brew mbal (sorghum beer) for the ceremony. On the day of the naming, a zibil (special Bura mat for rituals) is laid out on the floor of the hut of the mother of the twin on which she is required to sit while holding the babies. A white-feathered chicken is killed and 
used to prepare soup. Divar (mush made of guinea corn flour) is also prepared and served (with the soup) to the people gathered for the ceremony. The mbal is sieved and offered to the people as well. A traditional music performer plays gulum (long spiked-neck lute) music until the deaha names the child.

It is not any gulum player that is invited to perform at a naming ritual. The parents of the twin must consult the kwatika oracle who would determine which gulum player to invite for the ritual. ${ }^{3}$ Usually, the gulum musician performs tunes selected from a repertoire of praise songs. He praises the twin that is to be named. As the music proceeds, women take turns in the grinding of sorghum grains into flour on a quern-stone set in front of the musician. ${ }^{4}$ The procedure for naming, requires the deaha to select a name from a list-Thlama, Mwada, Bata, Awa, Pindar, Tagwi or Bala - reserved for only twins in Bura culture. It is believed that if the appropriate name among the culturally accepted names for twins is not given, it might as well affect his/her health and wellbeing. The parents too will be distracted. A twin must be healthy for the parents to focus on other things that could sustain the livelihood of the family. This is why the parents must consult the kwatika oracle to ensure that the right deaha and gulum player are selected for the ritual. In Bura worldview, it is not any deaha or gulum player that has the capacity to create a desired ritual atmosphere for the appropriate name given to a twin, but it is only the one specially selected by the kwatika oracle who may. The name given is, therefore, not chosen randomly from those dedicated to twins, as mentioned earlier. It is believed that the deaha is inspired by the gulum music to select the appropriate name. It is through the music that communication between him and some supernatural forces is established. Such supernatural forces communicate to him the name to give the child.

After the naming rituals, the health and wellbeing of twins are continuously monitored as they grow into adulthood. The parents are careful to monitor the maturity process and if at any time events similar to the ones discussed earlier are noticed, kamta bulikur, the second ritual must be performed immediately. This ritual is considered quite important because it determines whether or not twins will live a meaningful life. Indeed it is believed that if the ritual is not performed during the lifetime of a twin, such a twin could experience many difficulties. Thus, it is mandatory for every twin to experience the kamta bulikur ritual, especially before marriage. The ritual is deemed necessary so as to neutralize the powers twins are believed to possess, owing to their preternatural origin.

Again, as in the case of the naming ritual, traditional gulum music is of crucial significance in the kamta bulikur ritual. The kwatika oracle must equally determine all the key players in the ritual, i.e. the gulum player, the woman whose responsibility it is to place the ritual mat zibil and stands guard at the entrance to the hut, as well as the ritual friends. The ritual follows a similar pattern to that of the naming ceremony. In this case, however, it is the twin that sits on the zibil ritual mat, together with a ritual husband or wife, who is also carefully determined by the kwatika. If it is a male twin, a female youth is selected to act as his ritual wife and if she is female, a male youth is selected to act as her ritual husband. Another male and female are also appointed to act as their ritual friends. The selection is usually within the peer group of the

\footnotetext{
${ }^{3}$ An oracle in which the priest or priestess employs dancing as a medium through which answers to questions posed to it are determined.

${ }^{4}$ Quern-stones are stone tools for hand-grinding a wide variety of materials. They are used in pairs. The lower, stationary, stone is called a quern, while the upper mobile stone is called a hand stone. It is used by young Bura girls to showcase their grinding skills as a form of dance to the rhythm of gulum music.
} 
twin for whom the ritual is being performed. In each case, both the twin and his/her friend wear traditionally woven clothes (danciki for male and japta for female) for the ritual. Also, as part of the regalia for the ceremony, there are special brass bracelets and a ring (lia bulikur) worn by the twin and his/her friends. Cotton wool, roasted peanuts, and sesame (Sesamum orientale) are freely sprinkled on and around the ritual mat, the zibil, and some of it placed in a calabash as an offering. Other items placed around the zibil for the ritual include: divar tiksha (mush made out of the flour of a reddish sorghum), shifa (beer dregs) and shafa (tree whose leaves are used as taboo marks to protect property). A white-feathered chicken is slaughtered and the blood sprinkled over the shafa leaves. The same woman that lays the zibil stands guard at the entrance to the hut of the mother of the twin, where the ritual takes place, holding a knife (indla) and kutiku (narrow necked gourd for pouring oil). Her responsibility is to scare away the spirits that are thought to be associated with twins from having access to the twin that is undergoing the ritual process. She handles this task because as the one selected by the kwatika oracle to lay the ritual mat, it is believed that she is endowed with an extraordinary ability to recognize the unwanted spirits, who are being exorcized from a twin, and therefore drive them away with the indla and kutiku.

The gulum player sits right in front of the twin and his/her friends (but not on the ritual mat) and performs praise songs for the twin.

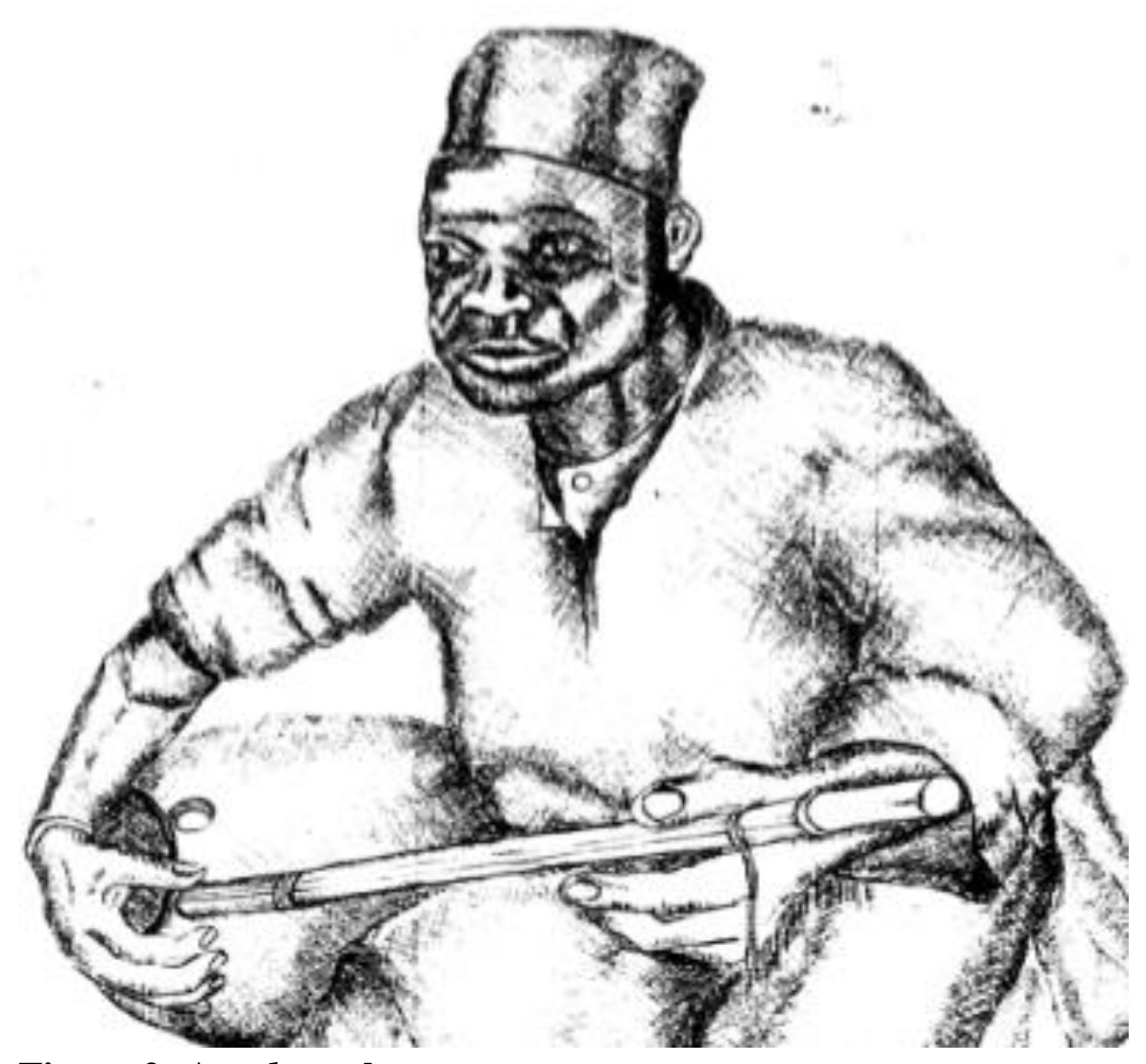

Figure 2: A gulum player

The praise songs continue until such a time that it becomes evident to the musician that the twin has been praised enough to "lure" him/her out of the preternatural world and reincorporated into the normal corporal world. As the musician performs and praises a twin, he observes the manner of his/her reaction to the music and it is through this that he determines when 
a twin has successfully been lured out of the preternatural world. The whole ritual process takes about an hour and it is normally held during the morning hours, preferably from 10 a.m. to 11 a.m. No specific reason is given for the choice of this time other than the people considering it the most convenient time of the day to perform the ritual.

Gulum music, according to Bura worldview, is key to appeasing a twin. It is a music that is understood in the "twin world" and, therefore, capable of attracting a twin to accompany the musician "home". There are no fixed songs for the ritual. Any musician selected by the kwatika for a specific kamta bulikur ritual is believed to come under the control of certain supernatural beings who instantaneously give the right songs to perform in each case. Song lyrics for various kamta bulikur rituals, therefore, differ. It appears the musicians use more of the physical, bodily, appearance of twins in composing the lyrics for the praise songs. One of the lyrics of such songs goes thus:

$$
\begin{aligned}
& \text { Ayee... ya } \\
& \text { Oh... } \\
& \text { Godita... (2x) } \\
& \text { Grateful... } \\
& \text { Iya godita ala giri }(2 x) \\
& \text { I am grateful to you } \\
& \text { Bzir mingil... mamza kuchir } \\
& \text { A dark...fair-nosed child }
\end{aligned}
$$

\section{Bzir mingil... mamza kuchir}

\section{Kita kanadi mwa liha kwan (3x)}

Be patient so that we can go home

The above song may be repeated extensively with the musician repeating many of the phrases used in praising the twin. From the song, it is evident that the gulum player addresses the twin with carefully selected words. He starts by expressing his gratitude and goes on to request that the twin be patient and accompany him home. "Home", as used in the song, implies that the gulum player and the twin live in separate worlds. However, through his music the gulum player is believed to have the ability to enter the supernatural realm and easily communicate with a twin and persuade him/her to leave the preternatural world. For the twin to accompany him home, he must, however, plead with him/her in a subtle way bearing in mind the fact that twins are believed to possess extraordinary powers and can choose to do things in their own way, if not treated appropriately. A musician's task, and the manner in which he executes it, are therefore very crucial in the ritual process. This perhaps shows why it is not any gulum player that can perform at a kamta bulikur ritual. For each kamta bulikur, the kwatika oracle, as earlier discussed, carefully decides on a specific gulum player for the ritual.

At the end of the ritual, all the items offered-sesame seeds, roasted peanuts, cotton wool, diva tiksha, shifa, and shafa - are collected and dumped at a fork of a road. Having gone through the ritual, the twin, for whom it was performed, is expected to live a normal life along with other members of the community. Through the ritual, "healing" takes place and all the negative things associated with twins are overcome and nothing again can hinder the health and wellbeing of a twin who undergoes it. 


\section{Conclusion}

Bura notions of twinship connote negativity with regard to the health and wellbeing of twins in the society. The negativity ranges from the use of the powers believed to be possessed by twins (i.e. to die and be born by another woman, use of scorpions to harm people at will or feigning sickness at all times) to inability of twins to marry at the right age or even being unable to live a regular life. Such negatives, according to Bura worldview, are detrimental to the health and wellbeing of twins, as well as, the community at large. To counter the negatives, the people have developed an appropriate twin ritual thought to be necessary in guaranteeing the good health and wellbeing of a twin. Bura traditional gulum music is of great significance in the ritual as indicated above.

Traditional music is associated with the supernatural in many societies (Nettl, 1983, p. 40) and it is used to communicate with powerful beings (Basso, 1985, p. 253; Drewal \& Drewal, 1983, p. 105). This appears to be the case in the Bura rituals as well. Communication with a twin is considered only possible through gulum music. The music and its musician are, therefore, significant in achieving the desired end for which the rituals are performed - dispossessing a twin of the extraordinary powers he/she is believed to possess. It is important that the musician plays a key role in the rituals. He serves not only as one who plays a musical instrument but also as a kind of a priest. This is so because, as indicated earlier, he is the one who determines when a twin for whom the ritual is being performed has been sufficiently praised, resulting in $\mathrm{him} / \mathrm{her}$ agreeing to leave the preternatural world and follow him (the musician) home. While it is true that there are other aspects of the ritual (e.g. the things offered as sacrifice, a woman who stands guard to chase away the spirits, etc.), it is important to note that the end result of the ritual cannot be achieved without gulum traditional music.

It is also pertinent to observe that this same music is necessary in naming twins as discussed earlier. Even though the naming ritual and kamta bulikur are two separate rituals, gulum music plays a key role in both. A gulum player names a twin after sufficiently praising him/her. Similarly, a twin is dispossessed of his/her extraordinary powers after sufficiently being praised by a gulum player. In each case though, the musician must be careful in the selection of the praise words in order to give the right name or severe a twin from the preternatural world. Both rituals, in Bura worldview, are significant to the health and wellbeing of a twin, as well as, that of the society as a whole. For, if twins do not undergo the rituals, they do not live a normal life and could also constitute danger to the society as a whole. Traditionally, the Bura live in a collectivistic society, that is to say there is no recognition of individuality. What affects one family then affects directly or indirectly other members of the society. Owing then to the importance attached to the health and wellbeing of twins and the society as a whole, great attention is given to the rituals and gulum music plays a central role in them. 


\section{References}

Basso, E. B. (1985). A musical view of the universe: Kalapalo myth and ritual performances. Philadelphia: University of Pennsylvania Press.

Bechtold, M. L., Puli, S. R, Othman, M. O., Bartalos, C. R., Marshall, P., \& Roy, P. K. (2009). Effect of music on patients undergoing colonoscopy: A meta-analysis of randomized controlled trails. Digestive Diseases and Sciences, 54(1), 19-24.

Bittinger, D. W. (1939). Land of the monkey bread tree. Elgin, IL: General Mission Board, Church of the Brethren.

Chappel, T. J. H. (1974). The Yoruba cult of twins in historical perspective. Africa, 44, 250265.

Davies, J. G. (1954). The Biu book: A collation and reference book on Biu Division (Northern Nigeria). Zaria: NORLA.

Drewal, H. J., \& Drewal, M. T. (1983). Gelẹde: Art and female power among the Yoruba. Bloomington: Indiana University Press.

Enwall, M., \& Duppils, G. (2009). Music as a nursing intervention for postoperative pain: A systematic review. Journal of Perianesthesia Nursing, 24(6), 370-383.

Knox, D., Beveridge, S., Mitchell, L. B., \& MacDonald, R. A. R. (2011). Acoustic analysis and mood classification of pain-relieving music. Journal of the Acoustical Society of America, 130, 1673-1682.

Leroy, F., Olaleye-Oruene, T., Koeppen-Schomerus, G., \& Bryan, E. (2002). Yoruba customs and beliefs pertaining to twins. Twin Research and Human Genetics, 5(2), 132-136.

MacDonald, R. A. R., Kreutz, G., \& Mitchell, L. (2012). Music, health, and wellbeing. Oxford: Oxford University Press.

Meek, C. K. (1931). Tribal studies in northern Nigeria. London: K. Paul, Trench, Trubner \& Co.

Nettl, B. (1983). The study of ethnomusicology: Twenty-nine issues and concepts. Urbana: University of Illinois Press.

Oruene, T. O. (1983). Cultic powers of Yoruba twins: Manifestation of traditional and religious beliefs of the Yoruba. Acta Geneticae Medicae Et Gemellologiae, 32, 3-4.

Stewart, E. (2000). Towards the social analysis of twinship. British Journal of Sociology, 51(4), 719-737.

Pison, G., van Beek, W. E. A., \& Sala-Diakanda, M. (1999). L'Afrique, continent des jumeaux. Paris: Séminaire Antropologie de l'enfance, Institut national d'études démographiques.

Pison, G., van Beek, W. E. A., Sala-Diakanda, M., \& International Union for the Scientific Study of Population. (1989). Mortalité et société en Afrique au sud du Sahara. Paris: Institut national d'études démographiques.

van Beek, W. E. A. (2002). Why a twin is not a child: Symbols in Kapsiki birth rituals. Journal Des Africanistes, 7, 119-147.

van Beek, W. E. A., Pison, G., \& Sala-Diakanda, M. (1992). Mortality and society in subSaharan Africa. Oxford: Clarendon Press.

Zazzo, R. (1960). Les jumeaux, le couple et la personne. Paris: Presses universitaires de France. Zazzo, R. (1993). Reflets de miroir et autres doubles. Paris: Presses universitaires de France. 